\title{
Effect of parent income, learning ways, motivation on student's result study in SMK Solok regency
}

\author{
Misnaliza Musa ${ }^{1}$, Yunia Wardi ${ }^{2}$, Idris ${ }^{3}$ \\ ${ }^{123}$ Universitas Negeri Padang, Padang - Indonesia, (misnalizamusa@ymail.com)
}

\begin{abstract}
This research purposes is to find how the effect of parent income, the way of learning and student motivation to the result of study for student accountant program at SMK in Solok regency. This is descriptive, quantitative research, this research was conducted at SMK in Solok regency which conducted accountant competency. Technique to analyze data is using path analysis. The result of analysis show that 1 ) The parent income has significant effect to the way of students in learning, 2)The parent income has significant effect to student's motivation in learning, 3) the parent income and the way of learning have significant effect to the result of study, 5)Learning motivation does not have significant effect to the result of study.
\end{abstract}

Keywords: parents income, learning ways, motivation.

\section{Introduction}

Education is a way to improve the quality of human resources, to make it real, the government conducted a formal educational system at school in many stages of educational institution. One of some educational institution is SMK (Vocational school ). Vocational school purpose to prepare student whose competency in particular ability and skill, so they will be able to work in some vacancies. In Solok regency there are 12 vocational school, they are 9 state school and 3 private school. In This research, the writer only focus on 3 vocational school, namely SMK Negeri 2 Gunung Talang, SMK Negeri 1 X Koto Singkarak dan SMK Budi Mulia. Because the three vocational have accountant program student.

Of the parameter used to know the achievement obtained is the result of learning. Based on Sardiman (2009:28) the result of learning is the achievement such as knowledge, skill, and some of values. Based on observation, the researcher found that result in learning is not optimally yet. There are many students who could not master the learning material or they can't get the minimum score for every subject they learned,

The learning result got by the student is not the single factor. It also can be influenced by some factors they are internal factor and external factors. Internal factor is factor come from 
students own selves such as health, intelegency, talent, intention, motivation, and the way of learning. And external factor come from family, school, community and environment.

Based on observation, the researcher found student has low motivation, it is influenced by social status, parent economy condition, the previous research conducted by Sirin (2005) showed that economical status has positive influence to the learning motivation in new York. Parent economical status can be known by the condition of parent economy. Many parent still get salary under minimum a month ( based on standard of Solok regency minimum wage). The low income gave bad influence to the student in learning. Because there is no facility in learning. The parent whose higher income will be able to give their children better facility better than low income parent. The parent whose job and have good income will have more chance with their children at home better than low income parent, because low income parent are too busy to earn some money for their life

Based that, the family condition also influenced the result in learning, it can be caused by the way of learning and student's motivation. The student who has good motivation in learning can be recognized by their behavior and attitude in learning, With their own motivation, the student will be diligent in learning, try to find the solution from the problem they faced, they are easy to feel satisfied with the achievement that they gained, they are independent in doing anything and they can argue their opinion. So that the way of learning, it can be seen from the student's ability to gain the information and how the student manage the information. The student can learn the subject by some method. they are : participating in studying, independent learning, new method of learning, assignment, and the participating in examination.

Based on information from counselor teacher, the writer knows that averagely every classroom has 20 students and only 15 student who are able to show the good way in learning, but the other are not. It can be indicated by the student activity in their home, they seldom read the book in their house, they only wanted to study when they would get some examination. But more of them did not study at home, they will ask a help to the student who sit next to them in examination. In doing assignment given by the teacher, the student usually cheat their friends, they usually do the home work given by the teacher in the classroom before the teaching learning process being started that's way the result of learning is not optimal. Based on the phenomenon, so the writer propose the research whose title "Effect Of Parent Income, Learning Ways, Motivation On Student's Result Study In SMK Solok Regency"

The learning result is the ability gained by the student after conducting learning process. It can be indicated the alteration of their behavior, like quoted from Hamalik (2013:30) the prove that someone has learned is there is a alteration of some behavior, such as they can know something, or they can comprehend something

Based on Nana $(2008 ; 76)$ the learning result is the ability gained by the student after getting the experience in learning. The learning result is influenced by some factors, based on Slameto (2010:54-72), The factors that influent the result of learning are :

1. The internal factor a) Physic (health, disability), b) Psychology (intelligence, attention, the way of learning, intention, talent, motivation, maturity, preparation), c)fatigue

2. The external factor; a) the family (the way of parent in education, the relationship of the family member, the situation in the home, the economy, the parent comprehension, The culture background, b) school (method of teaching, curriculum, the relationship between teacher and student, the relationship between student and student, school discipline, the teaching equipment, the studying time in school, the standar of lesson, the school facility, the 
learning method, the homework), c) the society (student intention in society, mass media, the friend)

This research will focuses on the factor that influence the student learning result, the factor are the parent income, the way of learning, and the student motivation.

Based on Mankiew (2006:45) is a income got by someone based on the service given to a firm or his/her superior where he/she worked. Wahyu $(2007 ; 165)$ suggested that the income is a money received by some in a firm like wage, salary, or rental money, benefit, and some allowance. From the opinions above, we can conclude that all the result received by the family member through some business and some economy activity.

The way of learning is a internal factor which influence the learning result. According to Sumadji $(2011 ; 60)$ the way of learning is $t$ of behavior as a experience and interaction to the environment. Slameto $(2010 ; 82)$ said that the good way in learning purposes to get knowledge, attitude, and skill, the way used is become habit, this will have effect to student. The good way in learning will cause the good result, but the bad way in learning will cause the un optimal result, this is supported by Syaiful $(2011 ; 58)$ said that the secret of being success is having good way in learning. From the opinions above, we can conclude that the student's way in learning is attitude, strategy and habit conducted by the student in order to get result as they want

In the learning process it needs to pay attention to what can motivate the student to study well. Sardiman (2009:32) told that motivation is the support from the internal to do the activity to gain the goal. Dalyono (2007:57) told that motivation is a support to do a work. As the opinion above, Hamalik (2008:158) told that "motivation is a change of energy marked by the feeling and reaction to get the goal. As the Dimyati said that it is a mentality support to move the human attitude including the attitude in learning. Based on the opinion told by some expert above, we can conclude that motivation is a behavior that support someone to do a specific activity to get a goal, the learning activity will be more meaningful and more beneficial for the student whose good motivation in learning

\section{Method}

This research is descriptive, quantitative research, because it purposes to see how the effect between free variable and fixed. Based on Nazir (2003:55) this method describe situation and event, this method doesnot only describing phenomenon but also describing the relationship, examining hypothesis, making prediction to get the implication from a problem. This research was conducted at SMK se-Kabupaten Solok whose account program competency.

The school are SMK N 1 X Koto SIngkarak, SMK N 2 Gunung Talang and SMK Budi Mulia Kabupaten Solok. The time of the research was the second half of semester in year of 2016/ 2017. The population of this research was the first grade student and the second grade student with total number 1333 students.

The technique of taking samples is using stratified proporsional random sampling technique which which produce samples as the proportions of each groups based on grade in the population with total number 100 students. By comprehending the framework of theoretical mind, so the technique to analize data is jalur analysist. 


\section{Results and Discussion}

Path analysist is used to know how far the free variable effect $\mathrm{X} 1, \mathrm{X} 2$ and $\mathrm{X} 3$ influence the variabele $Y$, so the effect can be known instantly.

1. Path Analysist Sub Struktur I The Effect Of Aren't Income ( X1) To The Way Of Learning $\left(X_{2}\right)$ Variable exsogen variable constant with $\mathrm{t}$ examination : $\mathrm{Px}_{2 \times 1}=0,592$, $\mathrm{t}$ calculate $=5,557$ on Sig. $0,000<0,05$,it mean significant constant. The amount of the variable effect of parent income student way in learning, it is shown by mark R square as 0.350 or $35 \%$, the rest of that influenced by other variable.

2. Path Analysist Sub Struktur II The Effect Of Parent Income (X1) To Student's Motivation In Learning (X3)

Variable hexogen variable constant with $\mathrm{t}$ examination : Px3x1 $=0,416$, $\mathrm{t}$ calculate $=4,524$ on Sig. $0,000<0,05$,it mean significant constant. The amount of the variable effect of parent income student way in learning, it is shown by mark R square as 0.173 or $17 \%$, the rest of that influenced by other variable.

3. Path Analysis Sub Struktur III The Parent Income (X1), Student's Way Of Learning (X2) And Students Motivation In Learning (X3) To The Student's Learning Result (Y)

Exogen variable Coefficient with $\mathrm{t}$ examination : Pyx $1=0,310, \mathrm{t}$ calculate $=4.536$ on Sig. $0,000<0,05$,it means the Coefficient is significant $\mathrm{Pyx} 2=0,609$, t calculate $=8.639$ on Sig. 0,000 $<0,05$, it means the Coefficient is significant ; Pyx3 =0,032, t calculate $=0,513$ on Sig. 0,609 $>$ 0,05 , it means the Coefficient is significant . from the coefficient test above.

It get information that coefficient $\mathrm{X} 1$ to $\mathrm{Y}$ and $\mathrm{X} 2$ to $\mathrm{Y}$, both of them statistically means ( $\mathrm{t}$ calculation more that $\mathrm{t}$ tab and $\mathrm{X} 2$ to $\mathrm{Y}$ and $\mathrm{P}$ value under 0.05 But path coefficient from $\mathrm{X} 3$ to $\mathrm{Y}$ did not mean ( $\mathrm{t}$ calculated under $\mathrm{t}$ table and $\mathrm{p}$ value above 0.05 , so the process would be repeated by removing $\mathrm{X} 3$ from model.

Proposition become $\mathrm{X} 1$ and $\mathrm{X} 2$ have influence to $\mathrm{Y}$. from the result of data processing, we got path coefficient of hexogen path variable with the $\mathrm{t}$ value: $\mathrm{Pyx}_{1}=0,317$, $\mathrm{t}$ calculate $=4.740$ on Sig. 0,000<0,05, it means that it's path coefficient is significant ; $\mathrm{Pyx}_{2}=0,621$, $\mathrm{t}$ calculate $=9,285(\mathrm{t}$ table 1,66 ) on Sig. $0,000<0,05, t$ means that it's path coefficient is significant . the EFFECT of the parent income to the student's ;earning result was displayed by the value of $R$ square as 0,718 or $71,8 \% \mathrm{~s}$, the rest is influenced by other variable. 
From the substructure we can conclude the framework of research result as below:

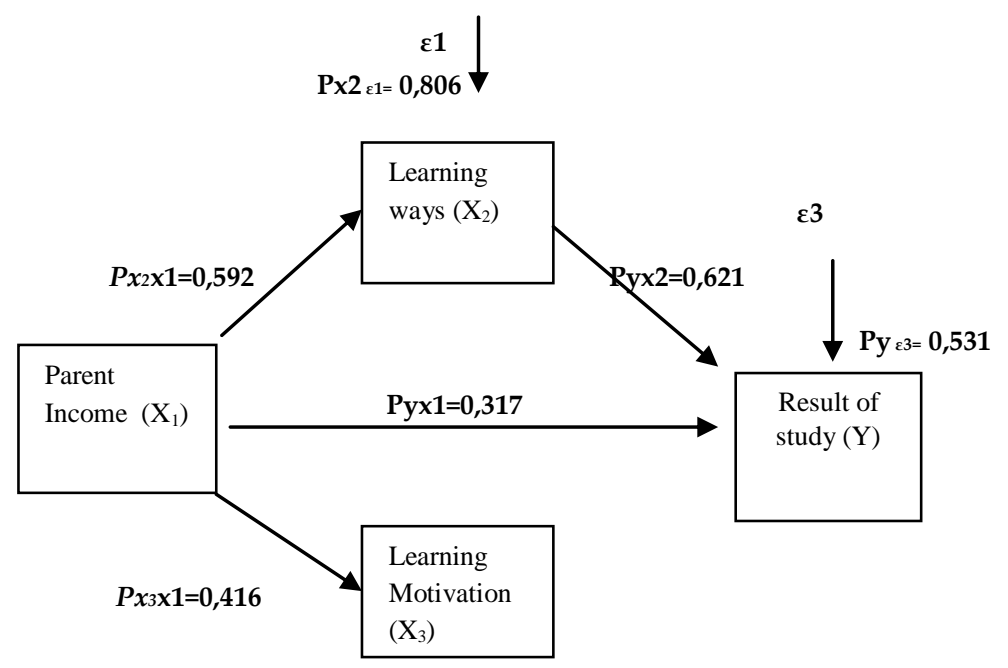

$P x 3 \varepsilon_{2} 0,909$

$\varepsilon 2$

picture 1: The Effect of Variable X1, X2,X3 \& Y

\section{Discussion}

The Effect Of Parent Income To The Of Student's Way In Learning At SMK In Solok Regency

Based on hypothesis test, it knows that the parent income has significant effect to the student's way in learning. The effect is positive, it means the student's way in learning will be better in their parent has better income, the analysis result is suit on Ahmadi and Supriyono $(2004 ; 88)$ who said that the poor family can't provide the proper learning place, and learning equipment, where the it need to make the effective and efficient learning. The poor family can't provide the fee for the learning necessities. particularities for the family whose many children. So, it can be concluded that the parent income give contribution to the student in learning, the student whose good income parent can fulfill their necessities.

\section{The Effect Of Parent Income To The Of Student's Way In Learning At SMK In Solok Regency}

Based on the hypothesis test, it is known that the parent income has significant effect to student motivation in learning at SMK student in Solok Regency. It means that the motivation is effected by the parent income, the better parent income. The higher student motivation in learning. It is suit on Soemanto $(2006 ; 205)$ although the student has high motivation, but it is not 
supported by the parent income, it will slowdown student in learning. The student who come from poor family sometime asked by their parent to work for earning a living. This can decrease student motivation in learning, furthermore the student need support from parent. It can be concluded that the parent income has significant effect to student motivation, the better parent income, the higher student motivation, on the other hand the worse student income, the lower student's motivation

\section{The Effect Of Parent Income To The Of Student's Way In Learning At SMK In Solok Regency}

Based on hypothesis test, the parent income has significant effect to student's learning result it could be seen that sign is less than 0.05 . it is suit on the relevant research that the parent income and the way of student in learning have significant effect to the learning result. It looked that variable the parent income has significant effect to the student's learning result. This research was suit on the theory the theory stated by lameto (2010:63)the family economy has correlation about how the student learn. The student has to study, but they also provide their necessities such as food, clothes, health insurance, etc. They also need some facilities such as the room to study, table, chair, light, stationery etc. These necessities only could be provided if they had enough money. Harun (2013) stated in his research that economy and social condition has role to the student 's learning result. The parent who come from good economical background would support and motivate their shildren to study, so the student can get the maximal result. Meanwhile the variable how they learn in this research found the result that the way of student in learning has significant effect to the learning result.

Based on the research, the way of learning is the most dominant variable in giving contribution to student's learning result. This is suit on opinion stated by Hasbullah $(1993 ; 43)$ that the way of learning is key factor to determine whether they will be success or not. The student whose good way in learning will get good result. It is supported by , Dalyono (2005;5758 ) he stated that te way of learning also influent the achievement in learning. Learning without technique and biology factor, psychology and health science will not get maximal result. These technique were also needed to be notice, how they erad, copy, make underline, make summary, what should be written or not, etc. Beside that, we should pay attention to the learning time, where they learn. The facility, learning media, the student should has learned efficiently so the they can get maximal result.

Based on the opinion above, the researcher conclude that the economy condition has effect to the result in learning and achievement gained by the children ( student). The parent whose high income can provide the facility to learn in their house, so it will the student's intenton to learn

On the other hand, if the parent has bad condition of their economy, so the parent can not provide their children's necessities to learn, it will cause the student becoming lazy, less motivated, so the result of learning is decreased. Motivating children to learn does not give 
significant effect to the student's learning result. This is not fit with the research that motivation has effect toward the learning result

There are different opinion about the research, it could be caused by the different environment, student's characteristic to the different school, and standar quality also different for each school. The learning result is not only influenced by one factor, but also influenced by many factors, this is stated by Dalyono (2009:55-60) "Factors which can effect the learning result can be devied into 2 , they are internal factor like (health, intelligency, talent, intention, motivation, the way in learning) and external factor like (family, school, society, environment)".these factors are related one another. It can be concluded that motivation does not effect directly to the student's learning result, because the learning result effected by health, intelegency, talent, the way in learning, and societies.

\section{Conclusions}

1. The parent income has significant effect to the student's way in learning at student of accountant program at SMK in Solok regency.

2. The parent income has significant effect to the student's motivation at student of accountant program at SMK in Solok regency.

3. The parent income, the way in learning, have significant effect to the student's learning result, but motivation does not effect the student's ;earning result significantly

\section{Acknowledgments}

In the research and writing of this Thesis many authors get help, encouragement, guidance from various parties, for that the authors thank to Mr. Prof. Dr. Yunia Wardi, Drs. M. Si as the main supervisor, and Dr. Idris, M.Si as Co-Counselor, who has provided input and suggestions and patiently guide the author in completing the research and writing of this thesis. writing is still there is a shortage, is expected to criticism and suggestions for the perfection of this paper.

\section{References}

Agus Irianto. (2010). Statistik Konsep Dasar, Aplikasi, dan Pengembangannya. Jakarta: Prenada Media Group.

Arikunto, Suharsimi. (2000). Manajemen Penelitian. Jakarta: Rineka Cipta

Abdillah, Agus. (2014). Pengaruh KondisiSosial Ekonomi Orang Tua, Fasilitas Belajar di Rumah dan Motivasi Belajar Terhadap Prestasi Belajar Mata Pelajaran Ekonomi Siswa Kelas XII SMA Negeri dan Swasta di Bukittinggi. Padang: UNP

Ahmadi, Abu dan Supriyono, Widodo. (2004). Psikologi Belajar. Jakarta: Renika Cipta

Ahmadi, Abu dan Supriyono, Widodo. (2009). Psikologi Sosial. Jakarta: Rineka Cipta

Ali Maksum. (2016). Sosiologi Pendidikan. Malang: Madani. 
Badan Pusat Statistik. (2013). Indikator Sosial Ekonomi Indonesia (Agustus 2013) dan IMF Word Economic Outlook Data Based.

Badan Pusat Statistik. (2013). Konsumsi dan Pengeluaran http://www.bps.go.id/subjek/view/id/5. Diakses 5 Mei 2017

Dalyono. (2007). Psikologi Pendidikan. Jakarta: Renika Cipta

Dimyati, Mujiono. (2015). Belajar dan pembelajaran. Jakarta:Renika Cipta

Fatimah, Djafar. (2014). Pengaruh Kondisi Sosial Ekonomi Orang Tua Terhadap Motivasi Belajar Anak.

Vol.2 no. 1. IAIN Sultan Amai Gorontalo

Gregory Mankiw. (2006). Makroekonomi. Jakarta: Erlangga.

Hamalik, Oemar. (2008). Proses Belajar Mengajar. Jakarta: Bumi Aksara

Harun Mashudi Achmadi. (2013). Pengaruh Motivasi Belajar, Latar Belakang Sosial Ekonomi Orang Tua Terhadap Hasil Belajar IPS Ekonomi Siswa. Untan

Hasbullah. (2005). Dasar-dasar Ilmu Pendidikan. Jakarta: PT. Grafindo Persada

Hasibuan dan Moedjiono. (2008). Proses Belajar Mengajar. Bandung: PT. Remaja Rosdakarya.

Idris. (2012). Aplikasi Model Analisis Data Kuantitatif dengan Program SPSS. Padang: Fakultas Ekonomi UNP

Khairanis, Arief. (2000). Perkembangan dan Belajar PesertaDidik Padang: FIP UNP

Muhibbin Syah. (2012). Psikologi pendidikan dengan Pendekatan Baru. Bandung: PT Remaja Rosdakarya.

Nana Sudjana. (2008). Penilaian Hasil Proses Belajar Mengajar. Bandung: PT. Remaja Rosdakarya

Nana Sudjana. (2011.Dasar-dasar Proses belajar Mengajar. Bandung: Sinar Algerisindo.

Nazir, Moch. (2003). Metode Penelitian. Jakarta: Ghalia Indonesia

Poerwadarminta,WJS. (2006).Kamus Umum Bahasa Indonsia. Jakarta: Bumi Aksara

Rahardja, Pratama dan Mandala Manurung. (2008). Pengantar Ilmu ekonomi (mikroekonomi dan makroekonomi). Jakarta: FEUI.

Riduwan dan Engkos Ahmad Kuncoro. (2012). Cara Menggunakan dan Memaknai Path Analysis (Analisis Jalur).Bandung: Alfabeta Bandung.

Rodiah. (2013). Hubungan Status Sosial Ekonomi Orang Tua dengan Hasil Belajar kompetensi Perawatan Kulit Wajah Bermasalah Siswa Kelas XI SMK Negeri 6 Padang, Padang: UNP.

Santoso, Singgih. (2000). SPSS. Jakarta: Alex Media Kompuutindo

Santrock, John W. (2007). Adolescence(Perkembangan Remaja). Jakarta: Erlangga

Sardiman, AM. (2009).Interaksi Motivasi Belajar Mengajar. Jakarta: PT. Raja Grafindo Persada. 
Sirin, Seleuk. (2005). "Sosioeconomic Status Academic Achievement: A Mete Analtic Review of Reserch" Journal Review of Education Reserch, Vol. 75, No. 3, pp 417-453. NewYork University Slameto. (2010). Belajar dan faktor-faktor yang mempengaruhinya. Jakarta: Renika Cipta Soemanto, Wasty. (2006). Psikologi Pendidikan. Jakarta: Rineka Cipta.

Syaiful Bahri Djamarah. (2008). Rahasia sukses belajar. Jakarta: Renika Cipta

Wahyu Adji, dkk.. (2007). Ekonomi Bagian Makro. Jakarta: Kanisius 